
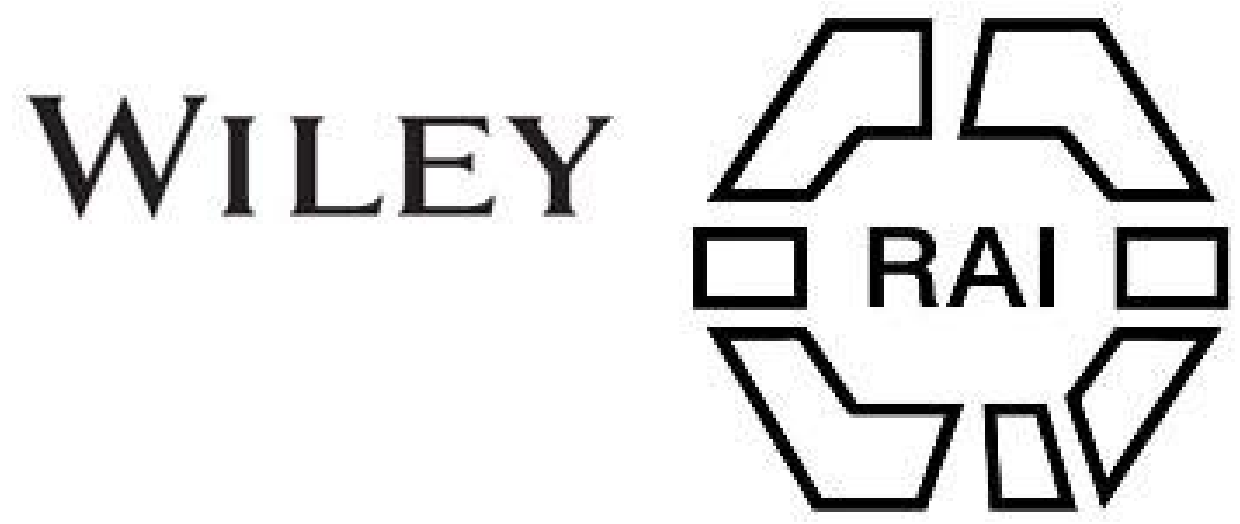

\title{
12. Masai Ear-Ring of Stone
}

\section{Author(s): A. C. Hollis}

Source: Man, Vol. 5 (1905), p. 22

Published by: Royal Anthropological Institute of Great Britain and Ireland

Stable URL: http://www.jstor.org/stable/2789009

Accessed: 27-06-2016 08:29 UTC

Your use of the JSTOR archive indicates your acceptance of the Terms \& Conditions of Use, available at

http://about.jstor.org/terms

JSTOR is a not-for-profit service that helps scholars, researchers, and students discover, use, and build upon a wide range of content in a trusted digital archive. We use information technology and tools to increase productivity and facilitate new forms of scholarship. For more information about JSTOR, please contact support@jstor.org.

Wiley, Royal Anthropological Institute of Great Britain and Ireland are collaborating with JSTOR to digitize, preserve and extend access to Man 
Masai Ear-ring of Stone. By A. C. Hollis, Local Correspondent of the Anthropological Institute.

This ear-ring belonged to a Masai boy of about fourteen years of age, and was used

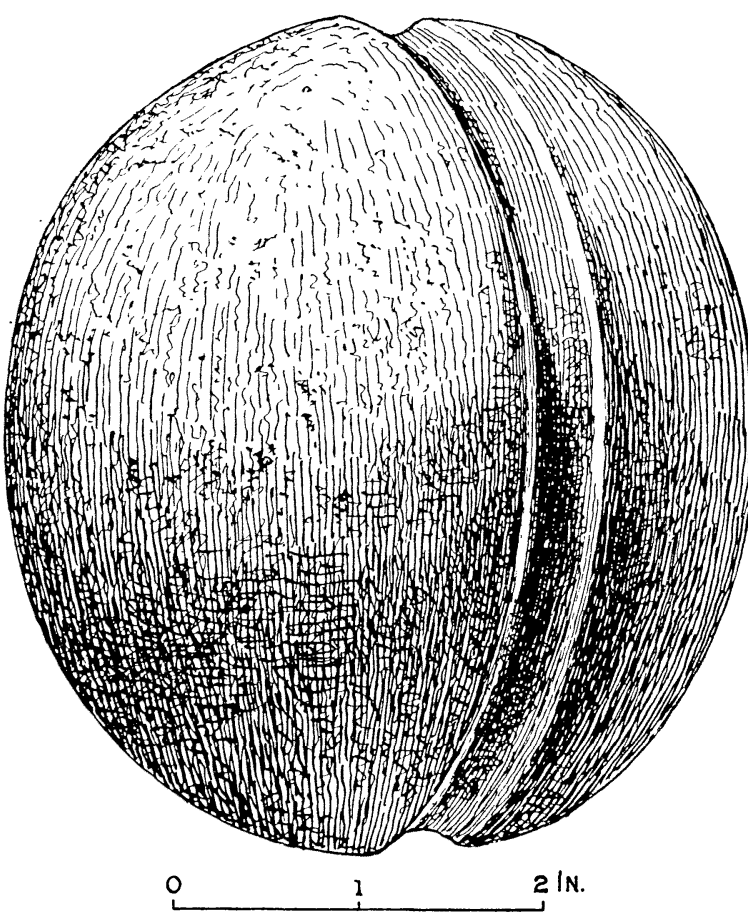
by him to distend the lobe of his ear. It measures $113 \mathrm{~mm}$. in diameter, and weighs $2 \mathrm{lbs} .14 \mathrm{oz}$

Masai children have their ears pierced when they are quite young, a thorn of a tree called ol-ngoswa (Balanites sp.) being used for this purpose. Boys and girls generally wear as earrings circular blocks of wood called 'n-gulalen, which are gradually increased in size as the lobe stretches. The lobes are said to have attained their correct length if they meet on the top of the head.

Stone ear-rings are not commonly worn by the Masai, and this is probably the only specimen in Europe. That it is not unique, however, is shown by the fact that the former owner appeared at my house the day after he sold it me wearing a precisely similar ornament. A. C. HOLLIS.

\section{Borneo.}

Haddon.

\section{Note on the Peoples of Borneo. By Ernest B. Haddon.}

The indigenous inhabitants of the island of Borneo have been designated in 13 the past under the general term of Dayak, but lately it has become evident that the word "Dayak" has no scientific value.

Dr. Haddon in 1901, in a Sketch of the Ethnography of Sarawak (Archivio per l'Antropologia e l' Etnologia, Vol. XXXI., 1901, p. 341), proposed to divide the inhabitants of the Raj into five groups: (1) Punan, (2) Kalamantan, (3) KenyahKayan, (4) Iban (Sea Dayak), and (5) Malay. At the conclusion of his sketch Dr. Haddon says : "Apart from the Negritos and Melanesians and undoubted emigrants "from the mainland of Asia, there are in the East Indiau Archipelago two races or " distinct varieties of man, the Indonesians and the Proto-Malays. Before the expansion " of the Orang Malayu [true Malays] most of these islands were inhabited by these " two races in variable degrees of purity or mixture. All the movements of the " population (irrespective of the undoubted Asiatic immigrations) that have occurred " in this Archipelago, say for a thousand years, have practically been confined to " peoples or tribes composed mainly of one of these two races or, more gemerally, of a " mixture of both in a differing amount."

In Augusı 1903 Dr. J. H. F. Kohlbrügge published the results of Dr. A. W. Nieuwenhuis' anthropometric investigatious in Netherlands Borueo. (Dr. A. W. Nieuwenhuis : "Anthropometrische Untersuchungen bei den Dajak." Bearbeitet durch Dr. J. H. 